高分子铪文集 (Kobunshi Ronbunshu), Vol. 35, No. 7, pp. 449-453 (July, 1978)

\title{
エビクロルヒドリンコムとその共重合コムの共橋かけに 及ぼすェーテル基の促進効果*
}

\author{
中村 儀郎*1 ・森 邦夫*1
}

(受付 1977 年 12 月 21 日・藉查終了 1978 年 2 月 18 日)

\begin{abstract}
要 旨 エビクロルヒドリンゴム (CHR) とそのエチレンオキシド共且合コムの共榙かけを Diak

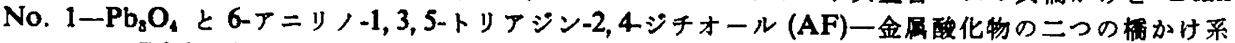
で行った. Diak No. 1- $\mathrm{Pb}_{3} \mathrm{O}_{4}$ 系仕 CHR と CHC の混合比に间倸なく，一定の桶加け速度と均一

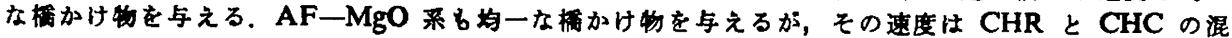

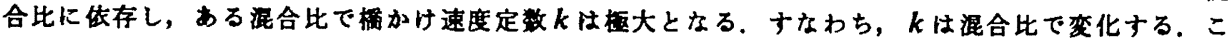
の極大となる混合比で活性化エネルギーは約 $18.7 \mathrm{kcal} / \mathrm{mol}$ とナへての混合比について最る低い值 を示した. 梗大镇 $k$ とこのときの湜合比は金属酸化物の影を受けた。. 以上の結果は, AF と $\mathrm{MgO}$ の反応で生成した $\mathrm{AF} \cdot \mathrm{Mg}$ が $\mathrm{CHR}$ と CHC 分子せグメント中のエーテル基の集合によって生成 したルイス㙁基の埸によりクラウンエーテルと同様の作用を受けて活性化されるためと棁明される。
\end{abstract}

\section{1 觜}

著者らは先にポリエチレングリコール誘学体が 6-R1, 3, 5-トリアジン-2,4ジチオールと MgOによるエピク ロルヒドリンゴム (CHR), 又はポリ塩化ビニルの灀か け反応を促進することを述べり，さらに低分子エチレン オキシド化合物ですエチレンオキシド，すなわち，エー テル基の集合から成る場が形成されるならば，やはり， チオレートフニオンが活性化されることを示しだ2.

一方，CHR とそのエチレンオキシド共重合ゴム (CHC) はそれぞれ 重合単位中に 1 又は 2 個のエーテル 基を有するのでこれらの混合ゴムの境界で程々の配位 をもったエーテル基の集合によるルイス塩基の場が形成 されるならば，楿かけ反応はこれらの影䇾を受けると推 定される.

本報では 6-フニリノ-1,3,5-トリアシンン-2,4シシチオー ル (AF) と金属酸化物に上る CHR と CHC 混合 の共檽かけ特性について検討し，エーテル基の場が檽か け反応に風与していることを示す。

\section{2 实}

\section{1 国合と混練}

CHR と CHC (いずれる日本ぜオン (株) 製 Hydrin

*本報を「高分子反応に及活す高分子镍中の活性セグ メントの効果 第 3 却」とする。

*1. 岩手大学工学部応用化学料（\$020 盛周市上田 4 T 目)
100, Hydrin 200; エピクロルヒドリンとエチレンオキ シドのモル比で 1:1), それぞれ 100 部はあらかじめカ 一ボン（旭カーボン(株) 製 \#60) 50 部をそれぞれブレ ンドして使用した．橋かけ配合混合コムはこれらを所定 の割合で 150 部取り， $40^{\circ} \mathrm{C} て 5$ 分間混練し，これに柏 か江郕 AF (三協化成(株) 製) 又は Diak No. 1 (へキ サメチレンジフミンカーバメイト,大内新興化学(株) $0.01 \mathrm{~mol}$ と金属酸化物 $\mathrm{MgO}, \mathrm{CaO}, \mathrm{BaO}, \mathrm{Pb}_{8} \mathrm{O}_{4} 5$ 部 (いずれる 400 メッシュ通過)を加えて，さらに5分間 混練して得た。

\section{2 杼かけ}

標かけ反応の速度定数 $k$ は上記の混合ゴムを使用して オシレイテングディスクレオメーター（(株)東洋精機製 作所製而型）により橋かけ曲線を测定し，これを一次ブ ロットして得られる直線の傾から求めだ).

CHR と CHC の共楀かけ物はやはり上記混合ゴムを $160^{\circ} \mathrm{C}, 30$ 分間ブレス加熱し, その後, 反応を完結させ ろためさらに $160^{\circ} \mathrm{C} て ゙ 120$ 分间オーブン加熱して得た。

\section{3 結果と考覀}

\section{1 湿合コムの加成性}

CHR と CHC の相容性の程度を示寸溶解度指数 $\delta$ は それぞれ $\delta_{\mathrm{CHR}} ： 9.35, \delta_{\mathrm{CBO}} ： 9.05$ 之近い值を示すこと から，両者は非常によく混合し，相分離しないことが予 想できる. したがって，CHR と CHC 混合コムにおい て両者の棌かけ速度が一定ならば，混合比之楿かけ度抽 よび物性值の間に加成性が成立するはずである。 


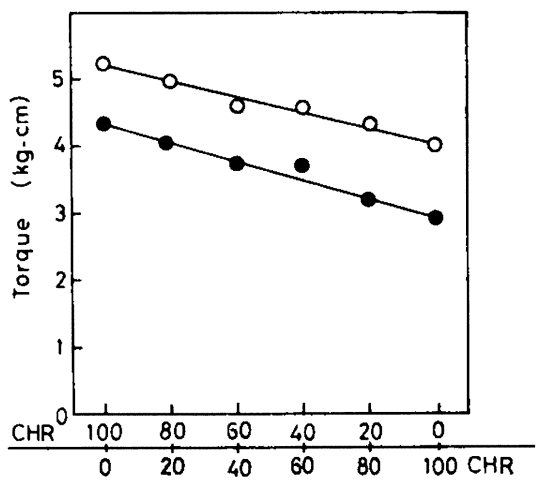

Fig. 1. Additivity of maximum torque in $\mathrm{AF}-\mathrm{MgO}$ system (O) and Diak No. $1-\mathrm{Pb}_{8} \mathrm{O}$, (O) at $160^{\circ} \mathrm{C}$.

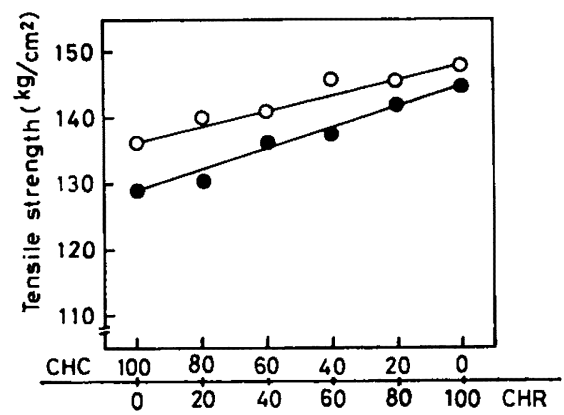

Fig. 2. Additivity of tensile strength in CHR-CHC rubbers crosslinked by $\mathrm{AF}-\mathrm{MgO}$ $(\bullet)$ and Diak No. 1- $-\mathrm{Pb}_{8} \mathrm{O}_{4}(\mathrm{O})$.

Fig. 1 から分かるように，橋かけ曲線から得られる 最終トルク (橋かけ度) と CHR一CHC 混合比の間に は㛢加系の違いに成係なく，良い加成性が成立する。 この結果は㛵かけ混合ゴム中の CHR とCHC のそれ ぞれの㛢かけ度が混合比に関係なく一定であることを示 している. 又,これは後述するよ5にCHR と CHCの 棉かけ点の反店性に差のないことの間接的根拠となる.

一方, Fig. 2 から共橋かけ物の引張り強度と混合比

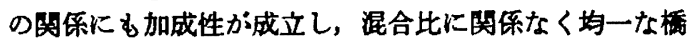
かけ物性を示すことが分かる。

\section{2 混合コムの满かけ性}

CHR と CHC の橋かけ点はゴム分子中のクロルメチ レン側鎖 $\left(-\mathrm{CH}_{2} \mathrm{Cl}\right)$ であり，前述の上らにそれぞれの 反応性に差がないと考えられる。すなわち，橋かけ系が 一定であれば CHR一CHC 湦合コムの棉かけ速度はど んな混合比でも一定であるはずである.

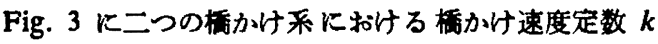
と混合比の関係を示した. Diak No. 1- $\mathrm{Pb}_{8} \mathrm{O}_{4}$ 㛢かけ

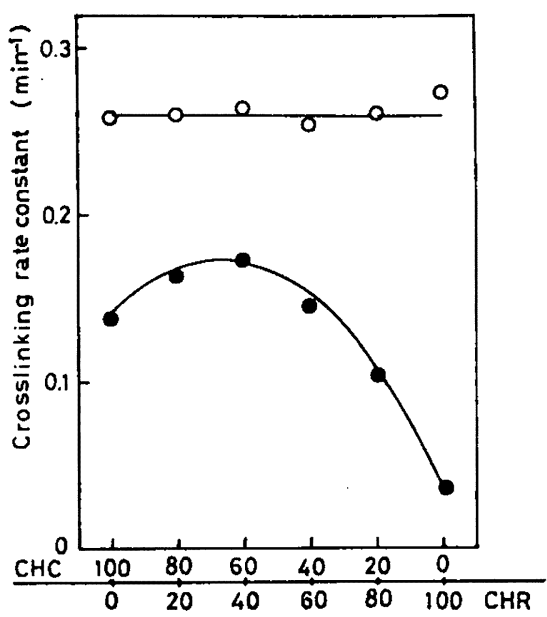

Fig. 3. Effect of Diak No. $1-\mathrm{Pb}_{8} \mathrm{O}_{4}(O)$ and $\mathrm{AF}-\mathrm{MgO}(0)$ crosslinking systems on rate constant for $\mathrm{CHR}-\mathrm{CHC}$ cocrosslinking at $160^{\circ} \mathrm{C}$.

系のよらなジフミン檄かけではやはり CHR とCHCの 混合比に関係なく， $k$ は一定である.これは CHR と CHC の橎かけ点の反応性が本筫的に差がないことを示 すむのである.

一方, AF-MgO 橋かけ系では上記の結果と全く巽 なり,CHR と CHC の橋かけ速度が違らだけではなく 混合比で極大の瀮かけ速度を示し, かつ Fig. 1 と 2 で 加成性が成立するが栝かけ速度の加成性は成立しないと いら興味ある举動が恩められる. しかしながらこの結果 から，CHR と CHC の霹かけ点の反応性に差があると 考えるべきではなく，この理由は以下述へるように求核 試薬の反応性がゴム分子の化学權造によって変化するた めである.すなわち，これは先報で述へたよらに，エー テル基の集合体が AF の SH 基を活珄化することを考

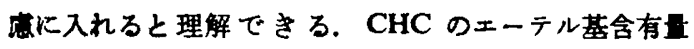
(酸素含量: 23.4\%) は CHR (17.3\%)のそれより高い ため, CHC はルイス塩基としての作用も強く， AF$\mathrm{MgO}$ 系の反応性を著しく高める.

CHR と CHC 混合ゴムの AF-MgO 棉かけにおけ

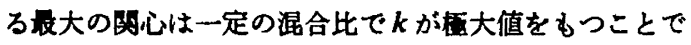
ある. Fig. 4 に混合比と $\boldsymbol{k}$ の関保を異なる橋かけ温度 について示した，便大を与える混合比はおよそ CHC/ $\mathrm{CHR}=65 / 35$ と CHC リッチであるが，この值は㰌か け温度に関保なく一定である (Fig. 5). さらにこの程大 值は檽かけ温度の上开とともにいっそ5增加する㑯向に ある.このような傾向は Fig. 6 の混合比と活性化エネ ルギーの成係からいっそら明らかとなり，極大となる混 合比で取も低い活性化エネルギーが得られる.これは明 らかに CHR と CHC の混合により AF-MgO 系が活 


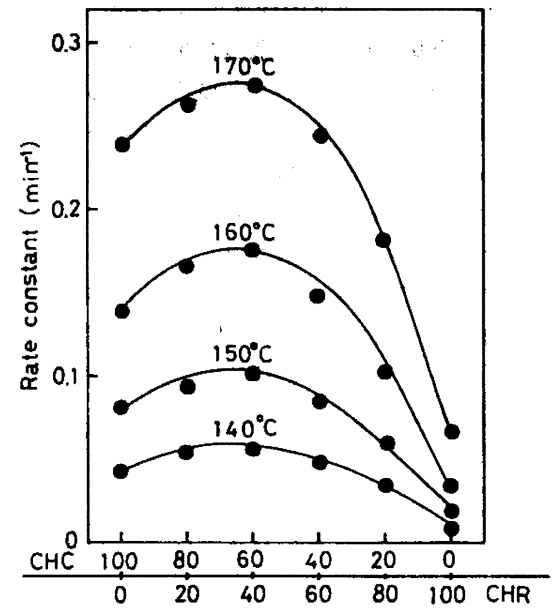

Fig. 4. Effect of crosslinking temperature on the relation between rate constant and CHRCHC mixing ratio.

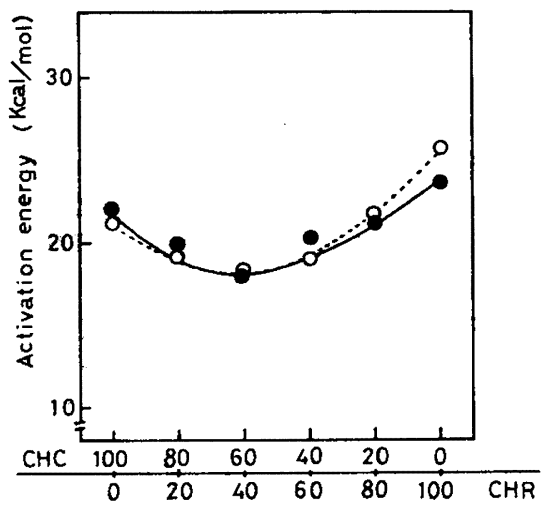

Fig. 5. Relation between activation energy and CHR-CHC mixing ratio: 9 , FEF carbone $40 \mathrm{phr}$; $\mathrm{O}$, Non-carbone.

性化されることを暗示している，すなわち，CHR一 $\mathrm{CHC}$ 混合ゴムにおける $\mathrm{AF}-\mathrm{MgO}$ 系の活性化は $\mathrm{CHC}$ 単独だけのものでなく, CHR と CHC の混合によって 生じたと考えるべきで，例えば混練ゴム中の CHR と CHC 粒子の境界で形成されるエーテル基の場が相乗的 に作用するためと考えられる.

又, Fig. 5 にはカーボン末添加についても示されて いるが，やはり同様の結果となって拈り，上記の促進奻 果にカーボンが関与していないことは明白である.

\section{3 金属酸化物の影電}

$\mathrm{AF}-\mathrm{MgO}$ 系の橋かけ反応は後述するように AF の $\mathrm{Mg}$ 塩 (AF・Mg) として作用するので, 金属酸化物が

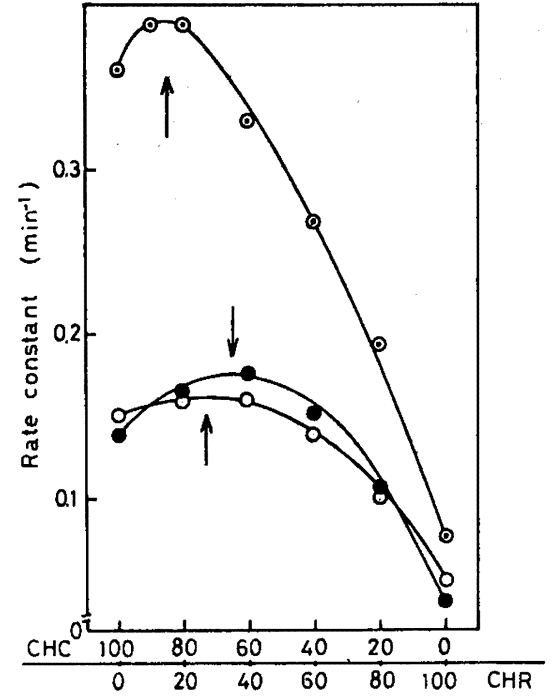

Fig. 6. Effect of metal oxides on the relation between rate constant and $\mathrm{CHR}-\mathrm{CHC}$ mixing ratio at $160^{\circ} \mathrm{C}: \odot, \mathrm{MgO} ; \mathrm{O}, \mathrm{CaO} ; \odot, \mathrm{BaO}$.

橋かけ速度に強く影響するはずである. Fig. 6 はCHR 一CHC 混合比と $k$ の関係は金属酸化物の種類の影響を 強く受け，極大值を与える混合比 (矢印) は酸性度が低 くイオン半径の大きい金属ほど CHCッッチの方にシフ トする. しかし，極大に批るkは必ずしも酸性度が低 い金属ほど高くはない，すなわち，Fig. 6 では金属酸 化物 5 部についての比較であるが，モル量の比較であこ の㑯向は変わらない，又この結果は，CHR お゙よび CHC 単独では金属の酸性度の增加とともに $k$ が增加す る傾向にあるのと比較すると興味深い。このような金属 酸化物による違いは，前述したようにCHR と CHCの 混合に上る橋かけ促進の相乗効果が金属の酸性度やイオ ソ半径と関係するため生じたと考えられる。

\section{4 橎かけ反忘の機满}

Diak No. 1- $\mathrm{Pb}_{3} \mathrm{O}$ 、橋加け系と AF-MgO 槜かけ 系による CHR，CHC の橋かけ反応を式 (1) (4) に示 す.

Diak No. 1- $\mathrm{Pb}_{8} \mathrm{O}$ 、系では, まず Diak No. 1 のて ミノ基が CHR，CHC のクロロメチレン基に求核攻慗 し, 橋加䞆と $\mathrm{HCl}$ を生成（式 (1)) する. その後受酸 凨 $\mathrm{Pb}_{8} \mathrm{O}_{4}$ と式 (1) で生成した $\mathrm{HCl}$ が反応 (式 (2))

して橋かけ反応は完結する。橋かけ反応の律速過程は式 (1) であり，式 (2) は橋かけ鎖の形成速度になんら関係 しないと考えられる.ささらに，ゴのよらな固溶体中で の反応であるから，CHR と CHC のクロロメチレン基 とフミノ基の反応は双極子一双極子間の求核膡換反応と して示され，橋かけ反応の $k$ は CHR と $\mathrm{CHC}$ で変わ 


$$
\begin{aligned}
& \text { - Diak No.1 - } \mathrm{Pb}_{3} \mathrm{O}_{4}
\end{aligned}
$$

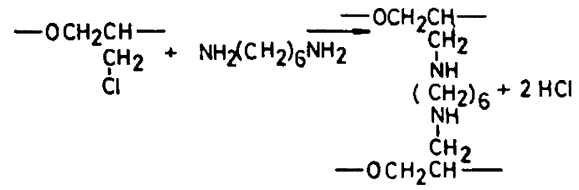

$$
\begin{aligned}
& \mathrm{HCl}+\mathrm{Pb}_{3} \mathrm{O}_{4} \longrightarrow \mathrm{PbCl}_{2}+\mathrm{H}_{2} \mathrm{O} \\
& \text { (AF.Mg) }
\end{aligned}
$$

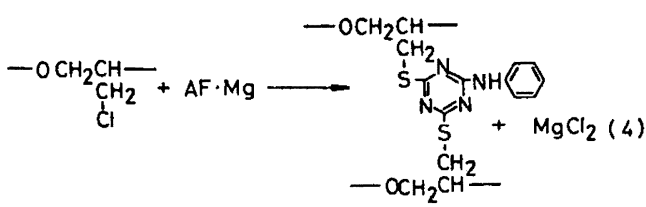

ることなく，いずれの混合比に㨟いても一定の $k$ を与え るわけである.

一方， AF-MgO 系では同し求核置換反応でも反応 の過程が異なる.すなわち，AF はへキサメチレンジフ ミンと異なり CHR, CHC と直接反応するのではなく, まず $\mathrm{MgO}$ と反応して式 (3) のように $\mathrm{AF} \cdot \mathrm{Mg}$ を生 成する.この反応はメタノール中では $60^{\circ} \mathrm{C}$ 以下です容 易に進行する。このようにして得られた $\mathrm{AF} ・ \mathrm{Mg}$ は橋 かけ温度になって初めて反応し，式 (4) の上うに橋かけ 鎖と $\mathrm{MgCl}_{2}$ を生成する. したがって，橋かけ反応の律 速は式 (4) の欈かけ鎖形成反応であることは Diak No. 1- $\mathrm{Pb}_{8} \mathrm{O}_{4}$ 系と同じである.

しかしながら， AF-MgO 系は Diak No. 1- $\mathrm{Pb}_{8} \mathrm{O}$ 、 系と異なり, 求核試薬はチオールの金属塩であるから, 双極子一イオン間の求核膡換反応として示される。強い 配位能力をもち，ルイス塩基であるクラウンエーテルけ が有機酸の金属塩を非極性溶剂にもイオン解離して溶解 させることとポリェチレングリコール（分子量 40,000) がロダンカリと錯体を形成することずを考えると，同じ くルイス塩基性のエーテル基を有する CHR， CHC む 橋かけ温度のような高温下で AF・Mg をイオン解離さ せ，求核置换反応を促進させることは可能である．した がって, ェーテル基含量の高いCHC は CHR より高 い橎かけ速度を示すことになる。

\section{5 促進好果}

著者らは先に 6-R-1, 3, 5-トリアシシン-2, 4-ジチオール と $\mathrm{MgO}$ による CHR とPVCの橋かけ反応においで1,
ポリエチレングリコール類が著しい促進作用を示し，特 に平㚬分子量 300 (エーテル基数：6７）のボリエチレ ングリコールが报も高い橋かけ速度を与えることを示し た。また，实戸らのはポリェチレンクリスール誘学体の 閉環反応の研究でェーテル基数 6 のものが樶も閉環しゃ すいことを報告していることから，上記の促進効果はク ラウンエーテル（エーテル基数 6) のように金属カチオ ンを捕捉してトリフジンチオレートフニオンを活性化す るためと考えた．したがって，CHC 中に扑る $\mathrm{AF}$ 一 $\mathrm{MgO}$ の高い桥かけ反応性注例之ば（I）のような CHC 分子のとる環状コンホメーションに $\mathrm{Mg}^{++}(\mathrm{AF} \cdot \mathrm{Mg})$ が捕捉されて,トリフジンチオレートフニオンの求核性 が增すためと考えられる. 又, $\mathrm{CHC}$ 中に批る AF・ $\mathrm{Mg}$ の配位は実際には（I）のよ5な平面的なものでな く,このよらなルイス塩基の場が立体的に形成されたも のであろら.

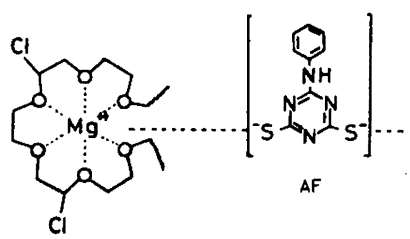

(I)

一方，著者らはPVC 粒子の表面に吸着したエーテル 基の集合が高分子鎖から成らなくても同様の举動を示 し, かつその作用は金属イオンの種類の影響を強く受け ることを示した2゙. 又, (I) のよらなエーテル基と金属 イオンの配位はエーテル基集合体の謤の大きさと金属イ オンのイオン半径の影敏を強く受け， AF・金属塩につ いてそれぞれ取意なむのがあるはずである。すなわち，

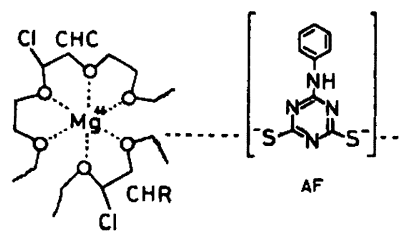

(II)

$\mathrm{CHC}$ 単独より CHC と CHR のブレンド物の方が (II) のよ5に分子間又はそれぞれの粒子間の境界で種々のエ 一テル基の集合の場()，すなわち，ルイス塩基の集合の 場が形成されるため, CHR と CHC のある混合比て最 大の促進効果を示し，この混合比において金属のイオン 半径の点でよく配位できるェーテル基の集合の場の数が 最大に達したことになる．特に，このよらな奻果は CHR と CHC の涺合により発生したのであるから， CHR 粒子と CHC 粒子の界面においてこのよらな場が 形成されるものであろら．したがって，金属化合物の種 類によって取大の $k$ を与兄る混合比とそのときの促進作 
用の程度は異なるのである。

以上述べたように, 本研究は CHR-CHC の共橋か けといら実用的意味からだけでなく，高分子セグント の分子内又は分子間でとるコンホメーションが高分子反 応に大きな影率を及ぼす例として興味深い。

\section{文城}

1) 中村俄郎，森 邦夫，日本ゴム協会詰，49, 345 (1976).
2) 森 邦夫，中村 儀郎， 日本化学会誌， 1390 (1977).

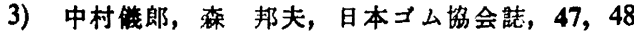
(1974).

4) J.J. Christensen, D.J. Eatough, R.M. Izatt, Chem. Revs., 74, 351 (1974).

5) P.V. Wright, et al., Polymer, 14, 589 (1973).

6) 穴戸晶彦，吉川英一，高分子， 26 (4)，260 (1977).

Accelerating Effects of the Ether Group on the Covulcanization of Epichlorohydrin and Its Copolymer Rubbers*

Yoshiro NAKamUra*1 and Kunio Mori*1

*1 Department of Applied Chemistry, Iwate University (Ueda 4-chome, Morioka 020, Japan)

Covulcanization of epichlorohydrin rubber (CHR) and epichlorohydrin-ethylene oxide copolymer rubber (CHC) has been investigated by using two vulcanizing systems, and the accelerating effect by the ether groups has been discussed. The vulcanization by Diak No. $1-\mathrm{Pb}_{8} \mathrm{O}_{4}$ gave a constant rate and a homogeneously vulcanized rubber regardless of the mixing ratios of CHR and CHC. The vulcanization by 6-Anilino-1, 3, 5-triazine-2, 4-dithiol (AF)-metal oxide, however, had a rate which was dependent on the mixing ratio, although it also gave a homogeneously vulcanized rubber. The activation energy was the lowest, about $18.1 \mathrm{kcal} / \mathrm{mol}$, for the reaction with the mixing ratio which gave the maximum rate. Both the maximum rate constant and the mixing ratio to give the maximum rate were influenced by metal oxides used as activator. The results are explained by the activation of the $\mathrm{AF} \cdot \mathrm{Mg}$ formed in the reaction of $\mathrm{AF}$ with $\mathrm{MgO}$ : the aggregation of the ether groups in $\mathrm{CHR}$ and CHC segments forms a Lewis basic field, which acts just like a crown ether and activates the AF $\cdot \mathrm{Mg}$. KEY WORD Epichlorohydrin Rubber / Ethylene Oxide Copolymer / Covulcanization / 6-Anilino-1, 3, 5-Triazine-2, 4-Dithiol / Crown Ether / Lewis Base Field / Aggregation of Ether Group /

(Received December 21, 1977: Accepted February 18, 1978)

[Kobunshi Ronbunshu, 35(7), 449-453 (1978)] 